\title{
Bioavailability of heavy metals in soils amended with sewage sludge
}

\author{
M. T. Morera, J. Echeverría, and J. Garrido \\ Departamento de Química Aplicada, Universidad P'blica de Navarra, Campus Arrosadía, \\ 31006 Pamplona, Spain. (e-mail: j.garrido@ unavarra.es). Received 21 September 2001, accepted 16 July 2002.
}

\begin{abstract}
Morera, M. T., Echeverría J. and Garrido, J. 2002. Bioavailability of heavy metals in soils amended with sewage sludge. Can. J. Soil Sci. 82: 433-438. The recycling of sewage sludge to agricultural land results in the slow accumulation of potentially toxic heavy metals in soils. A greenhouse experiment was conducted to determine the bioavailability of $\mathrm{Cu}, \mathrm{Ni}, \mathrm{Pb}$ and $\mathrm{Zn}$ applied to soils in urban anaerobically stabilized sewage sludge. The soils were Lithic Haplumbrept (Lh), Calcixerollic Xerochrept $(\mathbf{C x 1}$ and $\mathbf{C x 2}$ ) and Paralithic Xerorthent (Px). Sunflower plants (Helianthus annuus L) were grown in the soils following amendment with the sludge. The addition of sewage sludge markedly increased the average dry weight of the plants in the soils that had lower yields without sludge addition ( $\mathrm{Lh}, \mathrm{Cx} 2$, and $\mathrm{Px}$ ). The acid $\mathrm{pH}$ of the Lh soil favoured the bioavailability of $\mathrm{Zn}$ from sewage sludge. The bioavailability of $\mathrm{Cu}$ was greater in the alkaline soils than in the acidic soil (Lh), which can be attributed to the high organic matter content of the Lh soil which complexes $\mathrm{Cu}$ and impairs its uptake by the plants. The concentration of metals in the plants increased with the sewage sludge dose. The effect of the soil type on the metal concentration in plants was greater that the effect of the dose.
\end{abstract}

Key words: Soils, sewage sludge, heavy metals, bioavailability, sunflower

\begin{abstract}
Morera, M. T., Echeverría, J. et Garrido, J. 2002. Biodisponibilité des métaux lourds dans les sols bonifiés avec des boues usées. Can. J. Soil Sci. 82: 433-438. Le recyclage des boues usées sur les terres agricoles entraîne une lente accumulation de métaux lourds potentiellement toxiques dans le sol. Les auteurs ont effectué une expérience en serre en vue de déterminer la biodisponibilité du $\mathrm{Cu}$, du Ni, du Pb et du $\mathrm{Zn}$ incorporés au sol sous forme de boues usées urbaines stabilisées par anaérobiose. L'expérience portait sur du Haplumbrept lithique (Lh), du Xerochrept calcixerollique (Cx1 et Cx2) et du Xerorthent paralithique (Px). Les chercheurs ont cultivé des tournesols (Helianthus annuus L.) après avoir amendé le sol avec les boues usées. L'addition de boues augmente nettement le poids sec moyen des plantes sur les sols dont le rendement était plus faible avant bonification ( $\mathrm{Lh}, \mathrm{Cx} 2$ et Px). Le pH acide du Lh accroît l'absorption du $\mathrm{Zn}$ des boues par les plantes. La biodisponibilité du Cu est plus importante dans les sols alcalins que dans le sol acide (Lh). On l'attribue à la forte concentration de matière organique dans le Lh et à la formation de complexes avec le $\mathrm{Cu}$, ce qui empêche les végétaux d'absorber cet élément. La concentration de métaux dans la plante augmente avec la quantité de boues usées employée. Le type de sol agit plus sur la concentration de métaux lourds dans la plante que le volume de boues usées.
\end{abstract}

Mots clés: Sol, boues usées, métaux lourds, biodisponibilité, tournesol

The recycling of sewage sludge to agricultural land results in the slow accumulation of potentially toxic heavy metals in soils (Coker 1983). Once accumulated, heavy metals are highly persistent in the topsoil (Alloway and Jackson 1991) and can cause potential problems such as phytotoxicity (Berti and Jacobs 1996) or elevated transfer to the food chain (Page et al. 1987). The phytoavailability of heavy metals present in the sewage sludge depends on many factors such as the nature and amount of metal, degree of metal association in the sludge, soil, plant characteristics and weather conditions (Jin et al. 1996).

Trace elements are distributed in the soil in various forms: solid phases, free ions in soil solution, soluble organic-mineral complexes, or adsorbed on colloidal particles. The reactions of trace elements in soils include precipitation-dissolution, complexation-decomplexation, and adsorption-desorption processes (Kiekens 1984). All of these processes are directly or indirectly affected by $\mathrm{pH}$.
The addition of sewage sludge to soils could affect potential availability of heavy metals (Wang et al. 1997). The solubility and, consequently, the mobility of metals added with sewage sludge is controlled mainly by organic matter and oxides that act as principal adsorbents and can prevent excessive mobilisation of heavy metals (McBride 1995). We observed that the addition of an anaerobically stabilised urban sewage sludge to soils increased the percentages of metal extracted in non residual fractions: exchangeable, carbonates, Fe-Mn oxides and organic matter. Alkaline soils immobilised exchangeable $\mathrm{Zn}$ from sludge, but they did not show redistribution of $\mathrm{Cu}, \mathrm{Ni}$, and $\mathrm{Pb}$ (Morera et al. 2001).

Trace element accumulation in plants is a function of many variables and not simply a function of trace element applications in sewage sludge (Schmidt 1997). When the trace elements are in the soil solution at very low concentration or strongly retained in the soil phases, the plant may induce changes in the rhizosphere to increase their diffusion 


\begin{tabular}{|c|c|c|c|c|}
\hline & $\begin{array}{c}\text { Lithic } \\
\text { Haplumbrept (Lh) }\end{array}$ & $\begin{array}{c}\text { Calcixerollic } \\
\text { Xerochrept }(\mathrm{Cx} 1)\end{array}$ & $\begin{array}{c}\text { Calcixerollic } \\
\text { Xerochrept (Cx2) }\end{array}$ & $\begin{array}{c}\text { Paralithic } \\
\text { Xerorthent (Px) }\end{array}$ \\
\hline \multicolumn{5}{|l|}{ Particle size $\left(\mathrm{g} \mathrm{kg}^{-1}\right)$} \\
\hline$>50 \mu \mathrm{m}$ & 361 & 215 & 499 & 27 \\
\hline $50-2 \mu \mathrm{m}$ & 408 & 410 & 291 & 579 \\
\hline$<2 \mu \mathrm{m}$ & 231 & 375 & 210 & 394 \\
\hline Textural class & Loam & Clay loam & Loam & Silty clay \\
\hline Main clay minerals $\mathbf{z}$ & I & I & $\mathrm{M}, \mathrm{C}, \mathrm{I}$ & I \\
\hline Total $\mathrm{C}\left(\mathrm{g} \mathrm{kg}^{-1}\right)$ & 108 & 15 & 45 & 56 \\
\hline Inorganic $\mathrm{C}\left(\mathrm{g} \mathrm{kg}^{-1}\right)$ & 2.0 & 7.0 & 23 & 51 \\
\hline Organic $C^{\mathbf{y}}\left(\mathrm{g} \mathrm{kg}^{-1}\right)$ & 106 & 8.0 & 22 & 5 \\
\hline Total $\mathrm{N}\left(\mathrm{g} \mathrm{kg}^{-1}\right)$ & 4.5 & 2.0 & 1.3 & 1.8 \\
\hline $\mathrm{CEC}^{\mathbf{x}}\left(\mathrm{cmol} \mathrm{kg}^{-1}\right)$ & 17.3 & 23.9 & 10.7 & 14.8 \\
\hline $\mathrm{pH}$ (saturated paste & 5.0 & 7.2 & 7.9 & 8.1 \\
\hline Surface area $(B E T)^{\mathbf{w}}\left(\mathrm{m}^{2} \mathrm{~g}^{-1}\right)$ & 8.0 & 50 & 30 & 25 \\
\hline
\end{tabular}

$\mathbf{z}_{\mathrm{I}}=$ illite, $\mathrm{M}=$ montmorillonite, $\mathrm{C}=$ chlorite.

yObtained by difference.

${ }^{\mathbf{x}} \mathrm{CEC}=$ cation exchange capacity.

${ }^{\text {w }}$ Adsorption of $\mathrm{N}_{2}$ at $77 \mathrm{~K}$.

into the root. On the other hand, different mechanisms could enable plants to tolerate elevated concentrations of metals in the soil (Baker 1981). One is called "excluder" mechanism whereby the plant blocks the translocation of metals from the root in order to reduce the accumulation in the leaves. Another physiological mechanism is saturation of the system, which is responsible for transporting metals into the root. McBride (1995) postulated that root avoidance of a surface-contaminated soil layer may reduce metal uptake by plants growing in sludge-amended soils.

The primary objectives of this study were to determine the availability of $\mathrm{Cu}, \mathrm{Ni}, \mathrm{Pb}$ and $\mathrm{Zn}$ from municipal sewage sludge to sunflower plants, in four soils with different physico-chemical properties; to evaluate the influence of sewage sludge dose and soil type on the bioavailability; and to investigate the interactions among these variables.

\section{MATERIALS AND METHODS}

\section{Soils and Sewage Sludge}

Surface horizons $(0-15 \mathrm{~cm})$ of four soils were collected in Navarra, Spain. According to Soil taxonomy (Soil Survey Staff 1975), the soils were Lithic Haplumbrept (Lh), Calcixerollic Xerochrept (Cx1 and $\mathrm{Cx} 2)$, and Paralithic Xerorthent (Px). The Lithic Haplumbrept was an acidic uncultivated soil, whereas Cx1, Cx2 and Px were alkaline and represented a large proportion of the agricultural area in Navarra. Chemical and physical soil properties (Table 1) were determinated on air-dried soils $(<2 \mathrm{~mm})$ as described by Echeverría et al. (1999). The sludge was collected from the Wastewater Treatment Plant of Arazuri, which receives domestic and industrial water from Pamplona, Spain. Prior to incorporation into the soils, the sludge was air-dried at room temperature, homogenised, and stored in unsealed plastic bags. The sludge had a $\mathrm{pH}$ of 7.3 , a water content of $68.3 \%$, and contained $22.6 \%$ organic C, $2.2 \%$ total N, $0.2 \%$ $\mathrm{K}_{2} \mathrm{O}$ and $3.5 \% \mathrm{P}_{2} \mathrm{O}_{5}$ on a dry weight basis. Mean concentrations ( $\mathrm{mg} \mathrm{kg}^{-1}$ dry matter) of heavy metals in the sludge were: $\mathrm{Zn}, 1503$; $\mathrm{Cu}, 325 ; \mathrm{Pb}, 201$; and Ni, 95. These concentrations are typical of those found in municipal sludges with low proportions of industrial sewage, and were far below the Spanish (Boletín Oficial del Estado 1990) and European (Community European Council 1986) limit values for agricultural use. Metals in the sewage sludge were fractionated using the Tessier et al. (1979) sequential extraction procedure. More than $10 \%$ of $\mathrm{Ni}$ and $\mathrm{Zn}$ were found in easily mobilizable forms, exchangeable and carbonates, whereas $\mathrm{Cu}$ and $\mathrm{Pb}$ appeared in somewhat more resistant forms, organic matter and residual fractions (Morera et al. 2001).

\section{Greenhouse Experiment}

Four-kilogram samples of each air-dried, sieved soil were thoroughly mixed in pots with the air-dried, ground, homogenised sludge to produce mixtures equivalent in the field to application rates of 0 (control), 80, 160, and $320 \mathrm{t}$ $\mathrm{ha}^{-1}$. Each treatment was replicated three times. Assuming an incorporation depth of $30 \mathrm{~cm}$, the doses of sewage sludge were $26.7,53.4$, and $107 \mathrm{~g}$ dry weight $\mathrm{dm}^{-3}$ for 80,160 and $320 \mathrm{t} \mathrm{ha}^{-1}$ application rates, respectively. These application rates were considerably greater than would be recommended in agricultural practice. Table 2 includes the sewage sludge dose for each treatment and the concentrations $(\mathrm{kg}$ $\mathrm{ha}^{-1}$ ) of $\mathrm{Zn}, \mathrm{Cu}, \mathrm{Pb}$ and $\mathrm{Ni}$ added to the soils for the different doses of sewage sludge.

All treatments received fertilization with $\mathrm{N}(500 \mathrm{mg}$ $\mathrm{NH}_{4} \mathrm{NO}_{3}$ pot $^{-1}$ ), and $20 \%$ ( $\mathrm{vol} / \mathrm{vol}$ ) of perlite to improve aeration. After the addition of sewage sludge, the potted soils were watered with deionized water to approximate field capacity and allowed to incubate for a month on a greenhouse bench. Five sunflower (Helianthus annuus L.) seeds were planted in each pot. Upon emergence, plants were thinned to two per pot in Cx1, Cx2 and Px soils; in Lh, three plants were cultivated because the pot was larger. Sunflower plants were allowed to grow until floral buds emerged. The plant growth depended on the soils and sludge doses. Plants growing in amended Lh soils were collected $19 \mathrm{~d}$ before plants cultivated in $\mathrm{Cx} 1, \mathrm{Cx} 2$ and Px soils. At harvest, roots, shoots and flowers were collected separately, washed with water to remove any attached particles, rinsed twice with deionized water, and oven-dried at $72^{\circ} \mathrm{C}$ for $72 \mathrm{~h}$. After dry- 


\begin{tabular}{|c|c|c|c|c|c|c|}
\hline Metal & $\begin{array}{l}\text { Sewage sludge } \\
\left(\mathrm{t} \mathrm{ha}^{-1}\right)\end{array}$ & $\begin{array}{l}\text { Metal added } \\
\left(\mathrm{kg} \mathrm{ha}^{-1}\right)\end{array}$ & Lh & $\mathrm{Cx} 1$ & $\mathrm{Cx} 2$ & Px \\
\hline \multirow[t]{4}{*}{$\mathrm{Zn}$} & 0 & 0 & $157 \pm 21$ & $16.8 \pm 0.8$ & $39.7 \pm 1.7$ & $28.7 \pm 0.0$ \\
\hline & 80 & 42 & $126 \pm 13.9$ & $19.8 \pm 1.0$ & $44.5 \pm 8.2$ & $32.7 \pm 4.1$ \\
\hline & 160 & 84 & $95.5 \pm 1.15$ & $20.1 \pm 0.9$ & $47.8 \pm 3.8$ & $30.0 \pm 2.2$ \\
\hline & 320 & 168 & $46.4 \pm 1.25$ & $26.6 \pm 1.3$ & $40.2 \pm 3.0$ & $30.0 \pm 3.3$ \\
\hline \multirow[t]{4}{*}{$\mathrm{Cu}$} & 0 & 0 & $7.86 \pm 5.61$ & $6.55 \pm 0.37$ & $12.6 \pm 0.67$ & $10.7 \pm 0$ \\
\hline & 80 & 9.1 & $9.52 \pm 0.41$ & $7.31 \pm 0.69$ & $13.8 \pm 2.58$ & $10.7 \pm 0.63$ \\
\hline & 160 & 18.2 & $8.70 \pm 1.15$ & $7.64 \pm 0.54$ & $21.1 \pm 2.68$ & $10.1 \pm 0.88$ \\
\hline & 320 & 36.4 & $6.40 \pm 0.62$ & $10.2 \pm 2.47$ & $13.9 \pm 0.49$ & $9.00 \pm 0.43$ \\
\hline \multirow[t]{4}{*}{$\mathrm{Pb}$} & 0 & 0 & $7.32 \pm 2.03$ & $3.58 \pm 0.29$ & $3.42 \pm 0.38$ & $4.42 \pm 0.63$ \\
\hline & 80 & 5.6 & $7.62 \pm 2.09$ & $3.83 \pm 0.80$ & $3.25 \pm 0.25$ & $4.91 \pm 0$ \\
\hline & 160 & 11.3 & $5.12 \pm 1.15$ & $3.50 \pm 0.25$ & $4.33 \pm 0.38$ & $4.58 \pm 0.52$ \\
\hline & 320 & 22.6 & $3.81 \pm 1.25$ & $3.92 \pm 0.80$ & $3.58 \pm 0.14$ & $4.08 \pm 0.58$ \\
\hline \multirow[t]{4}{*}{$\mathrm{Ni}$} & 0 & 0 & $8.45 \pm 3.32$ & $2.01 \pm 0.22$ & $3.00 \pm 0.75$ & $3.00 \pm 0.43$ \\
\hline & 80 & 2.7 & $3.57 \pm 0.71$ & $2.15 \pm 0.34$ & $2.92 \pm 0.53$ & $2.92 \pm 0.14$ \\
\hline & 160 & 5.3 & $2.74 \pm 1.14$ & $2.32 \pm 0.58$ & $3.08 \pm 0.38$ & $3.58 \pm 0.14$ \\
\hline & 320 & 10.7 & $2.02 \pm 0.74$ & $2.76 \pm 0.42$ & $2.87 \pm 0.38$ & $3.83 \pm 0.14$ \\
\hline
\end{tabular}

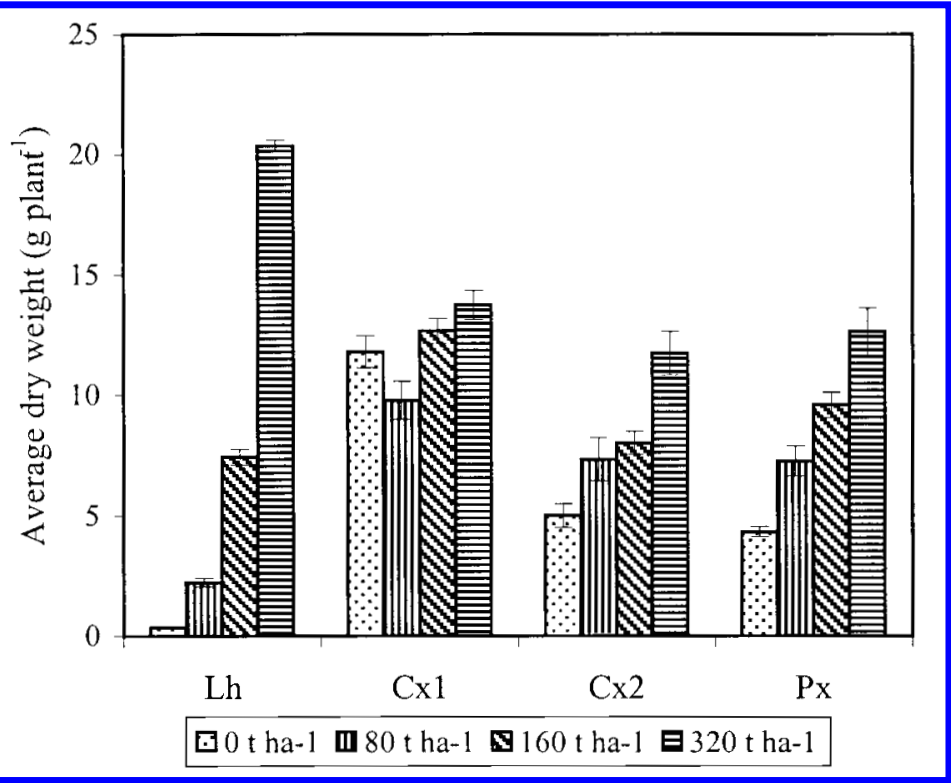

Fig. 1. Average dry weight of sunflower plants grown in soils amended with sewage sludge; results include the standard deviation. ing, plants were ground and stored in a sealed plastic bags placed inside a desiccator. After incubation, soil pH was measured in a 1:1 soil/water suspension after equilibration for $1 \mathrm{~h}$ (McLean 1982).

Plant $\mathrm{Cu}, \mathrm{Ni}, \mathrm{Pb}$ and $\mathrm{Zn}$ concentrations were determined on homogenised samples of each plant in each pot by nitric acid digestion (Jackson and Alloway 1991) and atomic absorption spectrophotometry (Perkin-Elmer, model 2100, <berlingen, Germany). The wavelengths were: $\mathrm{Cd}, 230.0$ $\mathrm{nm}$; $\mathrm{Cu}, 324.8 \mathrm{~nm}$; $\mathrm{Pb}, 283.3$; and $\mathrm{Zn}, 213.9 \mathrm{~nm}$. The flow rates were $3.0 \mathrm{~L} \mathrm{~min}^{-1}$ for air and 1.0 for acetylene.

Five subsamples of certified reference rye grass (CRM 281, Retieseweg, Belgium), containing similar trace element concentrations as the sunflower plants were included in addition to reagent blanks. The elemental concentration measurements were found to be comparable with certified values of the CRM sample.

\section{RESULTS AND DISCUSSION}

Figure 1 shows the average dry weight of the plants as a function of sewage sludge rates for the four soils. The addition of sewage sludge markedly increased the average dry weight of the plants in the soils with lower yields of dry vegetal matter for the control treatment. In control soils, the largest average weight corresponded to $\mathrm{Cx} 1$ soil $(11.8 \mathrm{~g}$ plant $^{-1}$ ), approximately 2.5 times bigger than the average weight of the plants grown in $\mathrm{Cx} 2$ and Px, and 35 times bigger than the average weight for Lh soil. Crop yield in Lh soil 

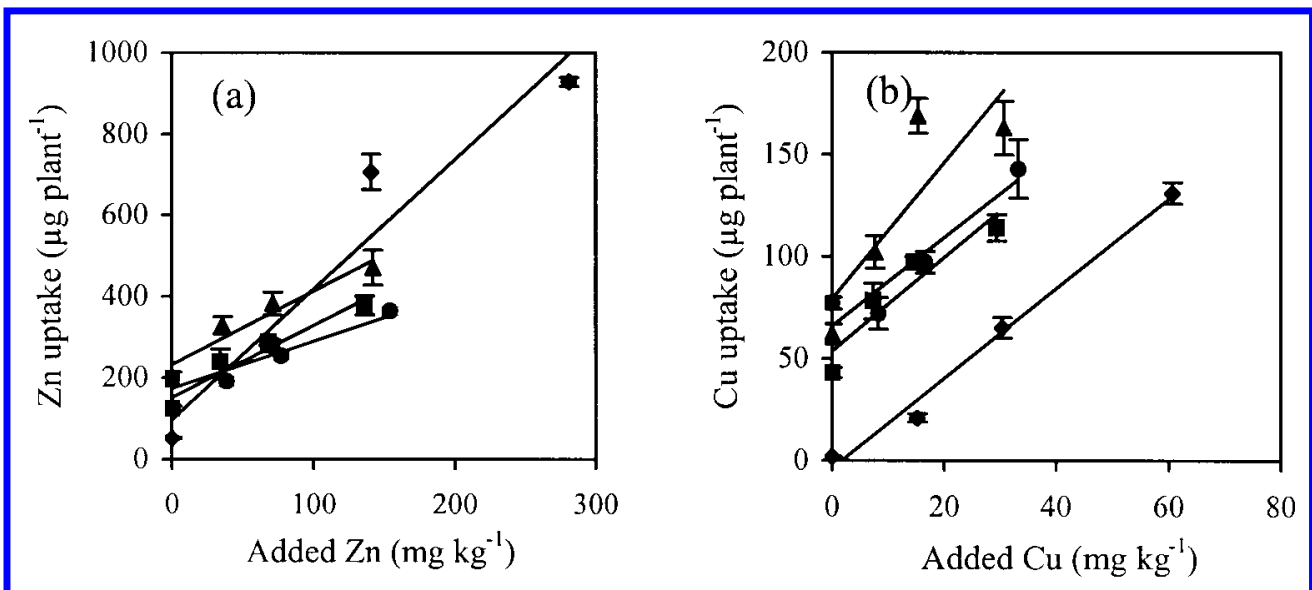

$\bullet \mathrm{Lh} \bullet \mathrm{Cx} 1 \wedge \mathrm{Cx} 2 \bullet \mathrm{Px}$
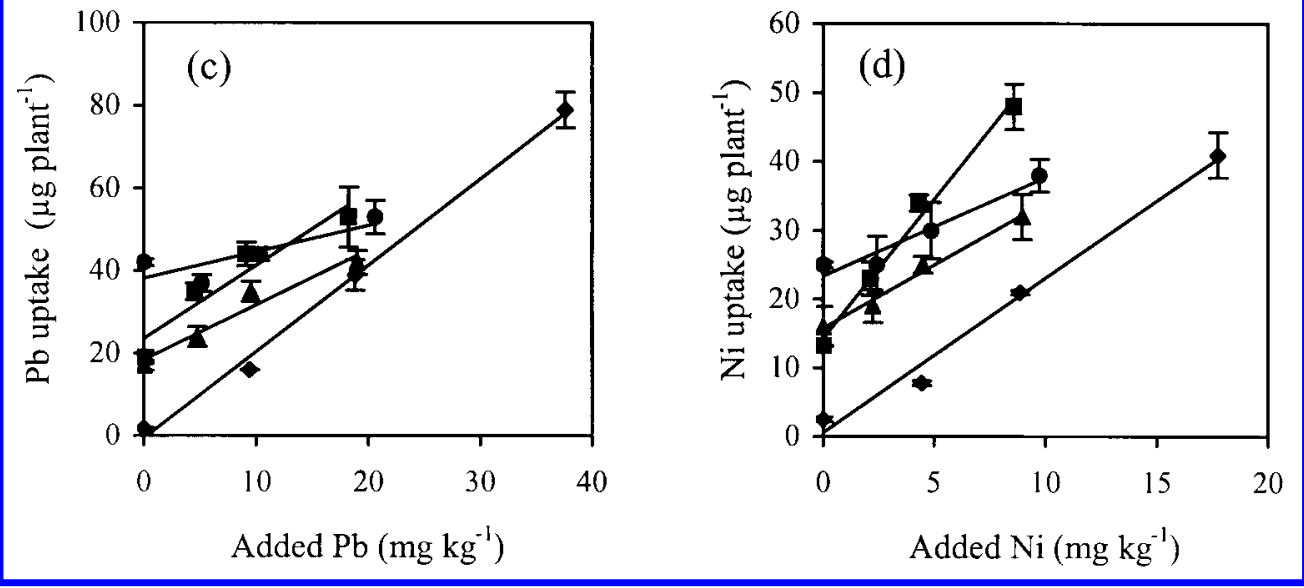

Fig. 2. Metal uptake by plants versus metal added to soils through sludge amendment: (a) $\mathrm{Zn}$; (b) $\mathrm{Cu}$; (c) $\mathrm{Pb}$; and (d) Ni. Results include the standard deviation.

was very low in the control treatment probably due to acid conditions, whereas reduced nutrient availability under alkaline conditions could explain the low yields in $\mathrm{Cx} 2$ and Px soils (Smith 1994). The rise in the productivity observed after applying sewage sludge is attributed to the increase in the nutrients available to plants (Rappaport et al. 1988; Wong et al. 1996), and in the acidic soil (Lh) also to the increase in the $\mathrm{pH}$ (Tadesse et al. 1991). Amendment with sewage sludge increased $\mathrm{pH}$ of $\mathrm{Lh}$ soil by one unit after application of $320 \mathrm{t} \mathrm{ha}^{-1}$, but it did not increase the $\mathrm{pH}$ of alkaline soils.

Figure 2 shows metal uptake by plants against metal added to the soil through sludge amendment. Metal uptake by plants increased more or less linearly as the added metal increased. The squared regression coefficients varied from 0.730 for $\mathrm{Cu}$ absorption by $\mathrm{Cx} 2$ soil to 0.995 for $\mathrm{Pb}$ absorption by Lh soil, and the slopes of the regression lines ranged from $0.644 \mu \mathrm{g}$ plant $^{-1} / \mathrm{mg} \mathrm{kg}^{-1}$ for $\mathrm{Pb}$ uptake by $\mathrm{Cx} 1$ to 4.05 for Ni uptake by Px soil. We did not see differences between nutrient $(\mathrm{Zn}$ and $\mathrm{Cu})$ and non-nutrient $(\mathrm{Ni}$ and $\mathrm{Pb})$ metal uptake. Although $\mathrm{Pb}$ slope was always the smallest, $\mathrm{Ni}$ slopes in $\mathrm{Cx} 1, \mathrm{Cx} 2$ and $\mathrm{Px}$ were higher than $\mathrm{Zn}$ slopes.

Table 2 shows the concentration of $\mathrm{Zn}, \mathrm{Cu}, \mathrm{Pb}$, and, $\mathrm{Ni}$ in the sunflower plants cultivated in the different soil-sewage sludge mixtures. The results are the arithmetic means of the values of the plants from the three pots of each treatment. The concentration of metals in plants was within the range of values usually found in references for different species of non-contaminated plants, with the exception of $\mathrm{Zn}$ in the $\mathrm{Lh}$ soil $\left(0 \mathrm{t} \mathrm{ha}^{-1}\right)$ whose concentration was higher (Fernandes and Henriques 1991; Kabata-Pendias 2001). Amendment of soils with sewage sludge produced opposite effects in the concentration of metals in plants. In the acid soil (Lh), the concentration of $\mathrm{Zn}, \mathrm{Cu}, \mathrm{Pb}$, and $\mathrm{Ni}$ decreased as the sewage sludge doses increased. In $\mathrm{Cx} 1, \mathrm{Zn}$ and $\mathrm{Cu}$ concentration in plants increased with increasing sewage sludge doses, whereas in $\mathrm{Cx} 2$ and Px soils, there were only minor changes in plant metal concentrations for the different experiments. 


\begin{tabular}{|c|c|c|c|c|c|c|}
\hline Source & $\begin{array}{l}\text { Degrees } \\
\text { of freedom }\end{array}$ & & $\mathrm{Zn}$ & $\mathrm{Cu}$ & $\mathrm{Pb}$ & $\mathrm{Ni}$ \\
\hline \multirow[t]{2}{*}{ Soil } & 3 & $F$ ratio & 300.2 & 43.7 & 11.1 & 9.32 \\
\hline & & $P$ value & 0.0000 & 0.0000 & 0.0000 & 0.0002 \\
\hline \multirow[t]{2}{*}{ Dose } & 3 & $F$ ratio & 25.6 & 4.92 & 2.30 & 6.33 \\
\hline & & $P$ value & 0.0000 & 0.0063 & 0.0966 & 0.0017 \\
\hline \multirow[t]{2}{*}{ Soil*dose } & 9 & $F$ ratio & 33.1 & 5.38 & 2.32 & 9.48 \\
\hline & & $P$ value & 0.0000 & 0.0002 & 0.0388 & 0.0000 \\
\hline
\end{tabular}

We carried out analysis of variance separately on each metal whose concentration in the plant was measured, for the factorial of four rates of sludge and four soils, with three replicates. A probability level of $P<0.05$ was accepted as significant. Statgraphics software version V4.1 (Manugistics 1998) was used for this purpose. The predictor variable, which was the concentration of each metal in plant, was statistically significant at the $99 \%$ confidence level (Table 3). In all cases, the effect of the soil type was larger than the dose; soil interacted with dose. The soil $F$-ratio was much larger for $\mathrm{Zn}$ than for the other metals.

Whatever the doses of sewage applied and type of soil, Zn was the metal with the greatest concentration in sunflower plants. These results are in line with the fact that $\mathrm{Zn}$ is also the metal that appears in greatest concentration in the sewage sludge, and that together with $\mathrm{Ni}$ is released in bigger percentages in the more mobile fractions, i.e., exchangeable and carbonates in the Tessier procedure (Morera et al. 2001). As shown in Table 2, Zn concentrations in plants were greater in the acidic soil than in the alkaline ones. These results confirm that $\mathrm{Zn}$ absorption depends on soil $\mathrm{pH}$ (Lübben et al. 1991; Smith 1994; Planquart et al. 1999).

There is controversy about the mechanisms proposed to explain the observed decrease in metal concentration in plants, like the Zn response in Lh soil. Corey et al. (1987), and Chaney and Ryan (1993) attributed the non-linear response to attenuation of metal bioavailability by increased sorption sites provided by the sludge constituents at the high sludge loading rates. Alternatively, McBride (1995) and Hamon et al. (1999) stated that physiological mechanisms, like saturation of the system responsible for transporting metal into the root or the blocking of translocation of metals from the root to the shoot, could result in the concentrationindependent uptake of metals. When applying Tessier's partitioning and selective extraction with DTPA solution to the different sludge-soil mixtures, the concentration of $\mathrm{Zn}$ extracted in non-residual fractions, and the concentration of Zn extracted with DTPA solution (Lindsay and Norvell 1978) increased linearly with the total concentration of $\mathrm{Zn}$ (Morera et al. 2001). Therefore, it is probable that plant physiological factors, and not attenuation of metal bioavailability by increased sorption of metals, were responsible for the observed plateau in plant $\mathrm{Zn}$ uptake in Lh soil (McBride 1995; Hamon et al. 1999).

The bioavailability of $\mathrm{Cu}$ was lower in the acidic soil (Lh) than in the alkaline soils. This may be partly explained by the large organic matter content of Lh soil that complexes
$\mathrm{Cu}$ and impairs its uptake by the plants. Moreover, the complexing capacity of the organic matter increases as a result of the rise of the $\mathrm{pH}$ after addition of sewage sludge. Among the soils of alkaline $\mathrm{pH}$, the availability of $\mathrm{Cu}$, like $\mathrm{Zn}$, was also markedly lower in the soil with larger carbonate content (Px). The chemical partitioning of $\mathrm{Cu}$ in soils amended with sewage sludge provided good indirect evidence to plant availability. In $\mathrm{Lh}$, approximately $98 \%$ of total $\mathrm{Cu}$ was extracted in the most resistant fractions (organic matter and residual), and only $2 \%$ of total $\mathrm{Cu}$ was extracted in oxides. In alkaline soils ( $\mathrm{Cx} 1, \mathrm{Cx} 2$ and $\mathrm{Px})$ the percentage of $\mathrm{Cu}$ extracted in the oxide fraction ranged from 8 to $17 \%$, whereas the total percentage of $\mathrm{Cu}$ released in organic matter and residual fractions was below 92\% (Morera et al. 2001).

In summary, the addition of sewage sludge markedly increased the average dry weight of sunflower plants, with lower yields of dry vegetal matter for the control treatment. Amendment of soils with sewage sludge produced opposite effects in the concentration of metals in plants. In the acid soil (Lh), and due to a dilution effect, the concentration of $\mathrm{Zn}, \mathrm{Cu}, \mathrm{Pb}$, and $\mathrm{Ni}$ decreased as the sewage sludge doses increased. In $\mathrm{Cx} 1, \mathrm{Zn}$ and $\mathrm{Cu}$ concentrations in plants increased when the sewage sludge doses increased, whereas in the Cx2 and Px soils, there were only minor changes in plant metal concentrations for the different experiments. The effect of the soil type on the metal concentration in plants was larger that the effect of the dose.

\section{ACKNOWLEDGEMENTS}

This work was supported by a project of Instituto Nacional de Investigación y Tecnología Agraria y Alimentación (INIA SC94-026).

Alloway, B. J. and Jackson, A. P. 1991. The behaviour of heavy metals in sewage sludge- amended soils. Sci. Total Environ. 100: 151-176.

Baker, A. J. M. 1981. Accumulators and excluders-strategies in the response of plants to heavy metals. J. Plant Nutr. 3: 643-654.

Berti, W. R. and Jacobs, L.W. 1996. Chemistry and phytotoxicity of soil trace elements from repeated sewage sludge applications. J. Environ. Qual. 25: 1025-1032.

Boletín Oficial del Estado. 1990. Madrid. 262: 32, 339-40.

Community European Council. 1986. Council directive of 12 June 1986 on the protection of the environment, and in particular of the soil, when sewage sludge is used in agriculture (86/278/EEC). Official J. Eur. Communities, No. L 181/ 6-12. 
Chaney R. L. and Ryan J. A. 1993. Heavy metals and toxic organic pollutants in MSW-composts: research results on phytoavailability, bioavailability, fate, etc. Pages 451-506 in H. A. J. Hoitink and H. M. Keener, eds. Science and engineering of composting: design, environmental, microbiological and utilization aspects. Renaissance Publishhing, Worthington, $\mathrm{OH}$.

Coker, E. G. 1983. Biological aspects of the disposal-utilization of sewage sludge on land. Pages 257-322 in T. H. Coaker, ed. Advances in applied biology. Academic Press, Inc. London, UK.

Corey, R. B., King, L. D., Lue-Hing, C., Fanning, D. S., Street, J. J. and Walker, J. M. 1987. Effects of sludge properties on accumulation of trace elements by crops. Pages $25-51$ in A. L. Page, T. J. Logan, and J. A. Ryan, eds. Land application of sludge applied trace constituents. Food chain implications. Lewis Publishing, Chelsea, MI.

Echeverría, J. C., Morera, M. T., Mazkiarán, M. C. and Garrido, J. J. 1999. Characterization of the porous structure of soils. Adsorption of nitrogen ( $77 \mathrm{~K})$ and carbon dioxide $(273 \mathrm{~K})$, and mercury porosimetry. Eur. J. Soil Sci. 50: 497-503.

Fernandes, J. C. and Henriques F. S. 1991. Biochemical, physiological, and structural effects of excess copper in plants. Bot. Rev. 57: $246-273$

Hamon, R. E., Holm, P. E., Lorenz, S. E., Mcgrath, S. P. and Christensen, T. H. 1999. Metal uptake by plants from sludgeamended soils: caution is required in the plateau interpretation. Plant Soil 216: 53-64.

Jackson, A. P. and Alloway, B. J. 1991. The bioavailability of cadmium to lettuce and cabbage in soils previously treated with sewage sludge. Plant Soil 132: 179-186.

Jin, Q., Zi-jian, W., Xiao-quann, S., Qiang, T., Bei, W. and Bin C. 1996. Evaluation of plant availability of soil trace metals by chemical fractionation and multiple regression analysis. Environ. Pollut. 91: 309-315.

Kabata-Pendias, A. 2001. Trace elements in soils and plants. 3rd ed. CRC Press, Boca Raton, FL.

Kiekens, L. 1984. Behaviour of heavy metals in soils. Pages 126-134 in S. Berglund, R. D. Davis, and P. L'Hermite, eds. Utilization of sewage sludge on land: rates of application and longterm effects of metals. D. Reidel, Dordrecht, The Netherlands.

Lindsay, W. L. and Norvell, W. A. 1978. Development of a DTPA soil test for zinc, iron, manganese, and copper. Soil Sci. Soc. Am. J. 42: 421-428.

Lübben, S., Rietz, E. and Sauerbeck, D. 1991. Metal uptake and crop growth on sewage sludge field trials with heavy metal contents near the recommended limit values. Pages 535-543 in P. L'Hermite, ed. Treatment and use of sewage sludge and liquid agricultural wastes. Elsevier, Amsterdam, The Netherlands.
Manugistics, Inc. 1998. Statgraphics Plus software, Version V4.1 Professional. Rockville, MD.

McBride, M. B. 1995. Toxic metal accumulation from agricultural use of sludge: Are USEPA regulations protective? J. Environ. Qual. 24: 5-18.

McLean, E. O. 1982. Soil $\mathrm{pH}$ and lime requirement. Pages 199-224 in A. L. Page, R. H. Miller, and D. R. Keeney, eds. Methods of soil analysis. Part 2. Chemical and microbiological properties. 2nd. ed. Soil Science Society of America, Madison, WI. Morera, M. T., Echeverría, J. C. and Garrido, J. J. 2001. Mobility of heavy metals in soils amended with sewage sludge. Can. J. Soil Sci. 81: 405-414.

Page, A. L., Logan, T. J. and Ryan, J. A. 1987. Land application of sludge-Food chain implications. Lewis Publishing, Chelsea, MI. Planquart, P., Bonin, G., Prone, A. and Massiani, C. 1999. Distribution, movement and plant availability of trace metals in soils amended with sewage sludge composts: Application to low metal loadings. Sci. Total Environ. 241: 161-179.

Rappaport, B. D., Martens, D. C., Reneau, R. B. and Simpson, T.W. 1988. Metal availability in sludge-amended soils with elevated metal levels. J. Environ. Qual. 17: 42-47.

Schmidt, J. P. 1997. Understanding phytotoxicity thresholds for trace elements in land-applied sewage sludge. J. Environ. Qual. 26: 4-10.

Smith, S. R. 1994. Effect of soil $\mathrm{pH}$ on availability to crops of metals in sewage sludge-treated soils. I. Nickel, copper and zinc uptake and toxicity to ryegrass. Environ. Pollut. 85: 321-327.

Soil Survey Staff. 1975. Soil taxonomy: A basic system of soil classification for making and interpreting soil surveys. US Goverment Printing Office, Washington, DC.

Tadesse, W., Shuford, J. W., Taylor, R. W., Adriano, D. C. and Sajwan K. S. 1991. Comparative availability to wheat of metals from sewage sludge and inorganic salts. Water Air Soil Pollut. 55: 397-408.

Tessier, A., Campbell, P. G. C. and Bisson, M. 1979. Sequential extraction procedure for the speciation of particulate trace metals. Anal. Chem. 51: 844-851.

Wang, P., Qu, E., Li, Z. and Shuman, L. M. 1997. Fractions and availability of nickel in loessial soil amended with sewage or sewage sludge. J. Environ. Qual. 26: 795-801.

Wong, J. W. C., Li, G. X. and Wong M. H. 1996. The growth of Brassica chinensis (L) in heavy-metal contaminated sewage sludge compost from Hong Kong. Bioresour. Technol. 58: 309-313. 


\section{This article has been cited by:}

1. Yanchao Bai, Tianyun Tao, Chuanhui Gu, Li Wang, Ke Feng, Yuhua Shan. 2013. Mudflat soil amendment by sewage sludge: Soil physicochemical properties, perennial ryegrass growth, and metal uptake. Soil Science and Plant Nutrition 59:6, 942-952. [CrossRef]

2. Seyed Majid Mousavi, Mohammad Ali Bahmanyar, Hemmatollah Pirdashti. 2013. Phytoavailability of Some Micronutrients (Zn and $\mathrm{Cu}$ ), Heavy Metals (Pb, Cd) and Yield of Rice Affected by Sewage Sludge Perennial Application. Communications in Soil Science and Plant Analysis 130923102343009. [CrossRef]

3. Hemmatollah Pirdashti, Alaleh Motaghian, Mohammad Ali Bahmanyar. 2010. EFFECTS OF ORGANIC AMENDMENTS APPLICATION ON GRAIN YIELD, LEAF CHLOROPHYLL CONTENT AND SOME MORPHOLOGICAL CHARACTERISTICS IN SOYBEAN CULTIVARS. Journal of Plant Nutrition 33:4, 485-495. [CrossRef]

4. R.P. Singh, M. Agrawal. 2008. Potential benefits and risks of land application of sewage sludge. Waste Management 28:2, 347-358. [CrossRef]

5. R.P. Singh, M. Agrawal. 2007. Effects of sewage sludge amendment on heavy metal accumulation and consequent responses of Beta vulgaris plants. Chemosphere 67:11, 2229-2240. [CrossRef]

6. Marnie L. Ward, Gabriel Bitton, Timothy Townsend. 2005. Heavy metal binding capacity (HMBC) of municipal solid waste landfill leachates. Chemosphere 60:2, 206-215. [CrossRef] 